Tatiana Chubarova ${ }^{1}$, Ivan Maly², Juraj Nemec $^{3}$

\title{
Public policy responses to the spread of COVID-19 as a potential factor determining health results: a comparative study of the Czech Republic, the Russian Federation, and the Slovak Republic
}

\begin{abstract}
The goal of this paper is to identify critical factors in success/failure of public policies focusing on fighting the spread of COVID-19 pandemic using a sample of three countries from Central and Eastern Europe with different results regarding COVID-19 morbidity and mortality rates, namely the Czech Republic, the Russian Federation, and the Slovak Republic. Based on comprehensive literature review, three independent variables were worked out: the scopelscale of public policy anti-pandemic interventions, the timing of public policy interventions, and the success of public policies in motivating compliance with anti-pandemic measures. Taking into account the similarity of measures introduced by national governments, the results suggest that the timing of public policy responses and success in motivating compliance may be critical factors in containing the pandemic.
\end{abstract}

KEYWORDS: Comparative analysis, anti-pandemic interventions, scope/scale of public policy, timing of public policy, compliance measures

RECEIVED 18 August 2020; ACCEPTED 26 September 2020.

\section{INTRODUCTION}

The number of publications related to the COVID-19 pandemic is growing exponentially. This is no surprise, due to its unique scale and impact on modern human history. Existing studies deliver single country as well as comparative perspectives, and focus on different aspects of COVID-19: epidemiologic, social, economic, and so on.

In some cases, the existing sources try to explain the varying (temporary) success rates of anti-pandemic policies implemented by national governments to limit the spread of COVID-19 (national morbidity and mortality ratios), mostly in single country studies. These authors try to define core factors determining the state success or failure in fighting the spread of the pandemic, such as competent politicians, high trust in society, reliable and professional bureaucracy, strong state, good economic situation, big welfare state, and low population density.

The aim of our article is to contribute to the discussion by identifying critical factors in the success/failure of public policies focusing on fighting the spread of the COVID-19 pandemic, using a qualitative comparative policy analysis method as the main research tool. As the sample, three countries from Central and Eastern Europe with differing results for COVID-19 morbidity and mortality rates were selected: the Czech Republic, the Russian Federation, and the Slovak Republic. Taking into account the research available, we suggested our original research methodology, based on expert opinions on the core factors determining the results of national anti-pandemic policies. This methodology allows us to test our own conception of causality, based on a combination of conditions (independent variables: scope/scale of public policy measures, timing of public policy measures, and securing compliance) that eventually produced the current COVID-19 mortality and morbidity rates in the three selected countries.

\footnotetext{
1 Senior Research Fellow, Institute of Economy, Russian Academy of Sciences, Moscow, Russia

2 Faculty of Economics and Administration, Masaryk University Brno, Czech Republi

3 Faculty of Economics and Administration, Masaryk University Brno, Czech Republic
} 
This kind of research is expected to deliver important added value to the current level of knowledge about the COVID-19 pandemic, especially because it proposes (but does not define) possible critical public policy factors determining the results of antipandemic measures.

\section{PUBLIC POLICY RESPONSES TO COVID-19: LITERATURE REVIEW}

Due to its scale and consequences, the COVID-19 pandemic has already been widely covered in the scientific literature. Most articles deal with health/epidemiological aspects of COVID-19 (e.g., Cascella et al., 2020). However, there are a number of academic publications that deal with socioeconomic and political aspects of the current crisis. The specific nature of the current period has been stressed, for example, by Bozorgmehr et al. (2020), who argue that the specific problem of Europe is that the COVID-19 crisis converges and interacts with three other global crises: governance, economic, and migration. Such a combination of critical factors makes the situation much more comprehensive and complicated. The criticality of the current crisis is also underlined by McKibbin and Roshen (2020). According to their study, the evolution of the disease and its economic impact are highly uncertain, which makes it difficult for policymakers to formulate an appropriate macroeconomic policy response. The seven different scenarios of the possible evolution of COVID-19 discussed in the paper demonstrate that even a contained outbreak could significantly impact the global economy in the short run.

A growing number of papers focus on public policies during the pandemic and factors determining the success or failure of different countries in containing the spread of this pandemic. Christensen and Lægreid (2020) present the example of how the Norwegian government has handled the COVID-19 pandemic, trying to determine the core success factors. The authors argue that a collaborative decision-making style with the involvement and participation of stakeholders is crucial, and coproduction between government actors and citizens is needed. However, some papers stress the opposite, arguing that a centralized top-down approach limiting certain democratic rights of citizens was the key success factor in Asia (e.g., Amat et al., 2020 or Ang, 2020).

Bouckaert et al. (2020) argue that the majority of European countries were not prepared for the COVID-19 pandemic. They stress the importance of contingencies, national administrative standard operating procedures in preparation for crisis situations, dynamic learning, fast feedback and accountability mechanisms, and problems arising from policy failure and blame avoidance.

In many cases, papers analyzing national experience with fighting the spread of COVID-19 also propose public policy-related factors influencing the extent of the spread of the pandemic in the country. For example, Peixoto et al. (2020) analyze timing and compliance as factors determining the situation in Portugal. Early timing is also mentioned as a success factor in other studies-Liu and Saltman (2020) argue that early centralized responses to COVID-19 spurred positive developments in China. Djalante et al. (2020) also stress the importance of "speed" when they provide detailed reporting and analyses of the responses to COVID-19 in Indonesia and highlight responses taken by the government, non-governmental organizations, and the community.

Some authors suggest that path dependency, in the sense of previous experience with similar crises (like SARS), helped in dealing with the COVID-19 pandemic in China (Liu and Saltman, 2020), Taiwan (Huang, 2020), and similar Asian countries as well as on other continents, for example, in Australia (Moloney and Moloney, 2020).

Shawa et al. (2020) analyze the responses of East Asian countries (China, Japan, and South Korea) and provide some commonalities and lessons. While countries have different governance mechanisms, a few governance decisions in respective countries did make a difference, along with strong community solidarity and community behavior.

According to WHO (2020), the highest priorities in fighting COVID-19 are to enhance whole-of-society coordination mechanisms to support preparedness and response, including health, transport, travel, trade, finance, security, and other sectors, sensitize the public to their active role in the response, engage with key partners to develop national and sub-national preparedness and response plans, and wherever possible, to build on existing plans, such as influenza pandemic preparedness plans, to ensure that space, staffing, and supplies are adequate for a surge in patient care needs. 


\section{METHODOLOGY}

This study is based on qualitative research approaches. Its main method is qualitative comparative policy analysis (Rihoux et al., 2011; Hudson and Kuhner, 2017), supported by other methods (literature review, expert opinion) described below. According to most authors, this method develops a conception of causality that leaves room for complexity. We try to define a combination of conditions (independent variables) that eventually produce a phenomenon — the outcome (dependent variable) to be explained.

For this study, the dependent variables are the health impacts of the COVID-19 pandemic: mortality and morbidity. The independent variable is the quality of public policy responses in the given country; to operationalize it, we conducted a comprehensive literature review. We searched for academic articles (search topic "public policy response COVID-19") via Google Scholar (305,000 results). From this huge number, we decided to check the first 200 articles and finally analyzed 40 articles related to our theme. Based on this comprehensive literature review and the conditions of selected countries, three independent variables were identified:

a) the scope/scale of public policy anti-pandemic interventions;

b) the timing of public policy interventions; and

c) the success of public policies motivating compliance with anti-pandemic measures.

The first two variables are discussed by a majority of studies and elaborated in-depth, for example, by the team of the Blavatnik School of Government, University of Oxford (Hale et al., 2020), that mapped government responses to COVID-19 across countries and time. However, we adopted their approach to fit to the conditions of the selected countries.

To define the set of critical anti-pandemic responses (Table 1), we used the Survey of Expert's Opinions method. In all three countries, we selected four experts each (medical staff or academics) and asked them to respond to a semi-open questionnaire, listing alternative policy responses. Experts were to rank the proposed measures and to add their own proposals or important responses.

Concerning the timing of responses, we used a modified approach. The core specific is the use of the "Day 0" (day when the first COVID-19 case was detected in the country), to create three specific time axes, each for one of the selected countries, focused especially on the responses defined by the experts as important or semi-important.

Our third point, the most critical and methodologically tricky, is to check if public policies motivated the general public to adhere to the announced anti-pandemic measures. To address this point, we relied on the opinion of the selected experts to construct Table 5 .

As subjects of our comparative analysis, we use three countries from Central and Eastern Europe: the Czech Republic (Czechia), the Russian Federation (Russia), and the Slovak Republic (Slovakia). The reason for such a choice was the factor of path dependency; all three countries belonged to the socialist bloc before 1989 .

The critical factor taken into account when selecting the sample were different COVID-19 health outcomes (mortality and morbidity indicators). The best performer from this point of view is Slovakia; Czechia is a good performer; and Russia is a limited performer (see Figure 1).

It should be mentioned that we are comparing countries that differ greatly in size. Russia has $17,100,000 \mathrm{~km}^{2}$ and 144.5 million inhabitants, Czechia has 78,866 km² and 10.69 million inhabitants, and Slovakia has 49,035 km² and 5.458 million inhabitants. However, the existing statistics clearly show that size does not matter in relative mortality and morbidity figures (some very small European countries are poor performers). The only problem with size is that in Russia, not all regions delivered the same scale and timing of public policy responses to COVID-19. Because of this heterogeneity, we focus on the national situation for Czechia and Slovakia, and the situation in Moscow with a federal overview for Russia.

The three countries in question have different political regimes. As indicated in the literature review, some authors suggest that more centralized countries had a greater capacity to apply strict anti-pandemic measures, restricting basic human rights (and because of this, their results are better). However, as the data from our sample show, the strictest set of measures was introduced in Slovakia, a European Union member since 2004. Taking this into account, we assume that the factor of different political regimes is not critical for our sample (this does not mean that this factor is irrelevant from a global point of view).

We collected the data about the situation in all three countries by monitoring national COVID-19 related sites (koronavirus. mzcr.cz, https://coronavirus-monitor.ru/, and www.korona.sk) and by monitoring at least three of the most popular newspapers in the analyzed countries (www.idnes.cz, www. pravo.cz, www.lidovenoviny.cz, www.kp.ru, www.rg.ru, www.mk.ru, www. pravda.sk, www.sme.sk, and www.novycas.sk). 
Fig. 1: COVID-19 spread in the selected countries (number of registered cases per 100,000 inhabitants, July 15, 2020)

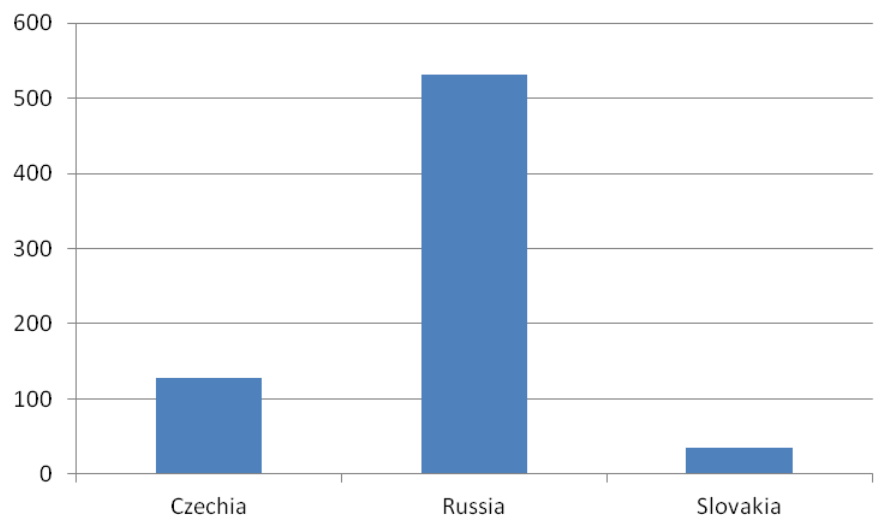

Source: authors

\section{COVID-19 MORTALITY AND MORBIDITY AND CORE GOVERNMENT RESPONSES IN THE THREE SELECTED COUNTRIES}

In Czechia, the first three COVID-19 cases occurred on March 1. A classical exponential increase of the new cases peaked at the end of March with 373 new cases on March 27, and then started to decrease gradually. From the end of April, the number of new cases remained mostly below 80 until June 24 . After the anti-pandemic measures were relaxed, the number of new cases quickly rose between June 27 and 29 back to the levels similar to those in April. By July 15, there were a total of 13,475 registered COVID-19 cases in Czechia (128 cases per 100,000 inhabitants); 355 patients had died and 8,679 patients had recovered. The number of tests conducted daily varied significantly, with a high of 9,383 tests on May 5, 2020; in total, approximately 600,000 tests have been conducted.

The Czech government's response (coordinated by the National Security Council and later via its committee the "Central Emergency Board") has been designed in close collaboration with epidemiological experts and focused on social distancing measures, protection of the most vulnerable population groups, diminishing the risk of importing the virus from abroad, and intensive testing. A massive emphasis on the obligation to wear face masks (and compliance with this duty) was a significant feature of the Czech response.

In Czechia, starting from the evening of March 10, 2020, the Health Ministry banned all cultural and sporting events of more than 100 people. The following day, students were banned from attending all schools. From 2 pm on March 12, when 118 cases had been confirmed, a 30-day state of emergency was declared. This was extended various times (as approved by the Chamber of Deputies) and ended on May 17, a few days after relaxing started. The main goal was to flatten the incidence curve as much as possible in order to prevent a collapse of the health system, especially intensive care facilities. This objective has been successfully achieved, thanks above all to the early response and a high level of compliance.

However, media, opposition, and a significant part of the public (including some "first-line" workers) have criticized the government because of the fragmented, often confused, and inconsistent communication, the lack of a systematic approach to a COVID-19 response, and rather late implementation of standard legal procedures foreseen by the law to deal with the crises. The country struggled heavily with the lack of protective equipment in the first weeks of the pandemic. Similarly, testing was not organized smoothly; the government failed to prepare adequate testing capacities.

The spread of COVID-19 in Russia has important specific characteristics. First, due to the size of the country, the virus spread gradually among its 85 regions like a wave, but in different phases. At the beginning, Moscow was among the first and worst-hit, but at present the situation there is much better and other regions contribute far more to the mortality and morbidity indicators. Second, because the first problems imported from China were quickly and locally stopped, the risks connected with the "European stream" of COVID-19 imports were underestimated. As a result, Russia registered 765,437 cases by July 15 (531 per 100,000 inhabitants) and 12,247 deaths. 


\section{Sciendo}

The first COVID-19 cases were reported in Russia on January 31, and the first measures were localized around the Chinese borders, including stopping tourist groups, issuing electronic visas, and limiting charter flights and railway connections. Russians who decided to come back from Wuhan were placed under state quarantine. On February 2, an emergency regime was announced in some Russian localities on the Chinese border, and the border was finally closed on February 20.

The reactions to the import of COVID-19 from Europe (especially from Italy) were delayed and measures developed gradually. They started with tightening border controls and a 14-day quarantine for those who came from abroad, then closing schools and universities, and canceling theater and concert performances, sports and other mass events, and the introduction of a self-isolation regime for the elderly and other people at risk. All these culminated in the introduction of self-isolation for all people in Moscow on March 30. Other regions gradually followed. Compared with Czechia and Slovakia, the first relaxing measures started in Moscow when the epidemiological indicators were still quite high.

Russia was quick to start COVID-19 testing and several test systems were developed by different research centers. By mid-July, the total number of tests was claimed to be approximately 24 million. From May 15, mass COVID-19 testing was started in Moscow to investigate the epidemiological situation.

Three major events were widely discussed during the pandemic in connection with anti-pandemic measures: voting for Constitutional amendments, the military victory parade usually held on May 9, and final state exams for school graduates. In the end, they were all postponed for safety reasons, but still took place later in times when morbidity remained significant. The military parade was held in Moscow on June 26, voting lasted a week (to avoid contact and secure social distancing) ending on July 1, and state exams started on the July 3. It is not yet clear how these events might have affected the numbers of infected.

Similar to Czechia and Slovakia, the level of compliance in Russia was relatively high and some control measures were in place, especially for those infected and their contacts. For example, electronic passes were introduced in Moscow allowing holders to move around the city under certain circumstances. However, the effectiveness of measures such as wearing masks and gloves in public places, especially shops and transport, was debated on the Internet and in mass media, which was likely to affect compliance. There were also some doubts internationally about the accuracy of national mortality statistics that pushed authorities to improve mortality data.

Slovakia registered only 1,951 cases (35 per 100,000 inhabitants) as of July 15, and only 28 people had died of COVID-19. The number of completed tests exceeded 235,000. Such positive figures were achieved in a very specific political situation, with national elections held on February 29, 2020, just before the outbreak of the pandemic; opposition parties won these elections and came into power in the midst of the crisis.

The first activities connected with the possible risks of the COVID-19 pandemic were announced and managed by the National Security Council. As early as February 14, a system was organized at the Slovak border to identify people who were ill. On February 27, the Security Council announced the first concrete anti-pandemic measures and activated the Crisis Crew, located at the Ministry of Health. After the first case appeared, a comprehensive set of anti-pandemic measures was announced, including a "restricted emergency situation”. All citizens were required to wear protective face coverings in all public spaces and advised to limit mobility of any kind. Other measures were home quarantine for 14 days for arrivals to the country (later, these people were required to stay in compulsory state-organized quarantine), closing almost all retail shops and services, prohibiting athletic, social, and cultural events, and closing of all schools and preschool facilities and all border crossings. A curfew was put in place during the Easter holidays, with limited exemptions. A few settlements of marginalized communities were in temporary full quarantine in April and May.

The first measures were relaxed starting in mid-May, and in mid-June the country returned to an almost normal mode of operation. However, in early July the number of new cases started to rise again (mostly imported cases, most of them from the Czech Republic and United Kingdom), but the situation remains under the control.

According to most experts, the positive health trends in Slovakia were achieved through very early and effective quarantine measures, and it should also be pointed out that Slovak citizens behaved very responsibly. The slogan "Stay at Home" was promoted and accepted; face masks were used regularly (even in July in most indoor spaces). However, not everything was perfect in Slovakiasimilar to the situation in Czechia, media and experts have criticized the government over fragmented, often confused, and inconsistent communication and the lack of a systematic approach to the COVID-19 response. The country also struggled heavily with the lack of protective equipment in the first few weeks. In contrast to Czechia, testing was organized smoothly and in a focused way, without significant delays (Slovak experts developed their own testing equipment). 


\section{THE SCALE OF PUBLIC POLICY ANTI-PANDEMIC RESPONSES}

The analysis in this section is based on the set of critical factors defined by the selected experts. According to these experts, the most important anti-pandemic measure was prohibiting mass activities (12 votes) followed by "compulsory quarantine," used in different forms by the sample countries (10 votes), and "closing borders" (10 votes).

Other critical measures were closing schools ( 8 votes) and mass and focused testing of people (7 votes). The Czech and Slovak experts also supported compulsory wearing of protective masks, especially in closed spaces. The Russian experts also mentioned specific restrictions on movement for citizens over 65 years of age and at-risk groups. However, our experts failed to support two proposed (and employed) measures: limiting movement within the country and closing shops.

Table 1, created on the basis of expert opinion, indicates that the scale of responses was very similar for all three countries. The only unique measure was the introduction of the state organized quarantine in Slovakia and to an extent also in Russia (in Slovakia, any person, except for specific cases such as truck drivers, was transported to a state-selected establishment after crossing the border, and required to stay there for a minimum of 14 days in full quarantine).

Tab. 1: Anti-pandemic spread measures in all three countries

\begin{tabular}{llll}
\hline & Czechia & Russia & Slovakia \\
\hline Prohibition of mass activities & Yes & Yes & Yes \\
\hline Compulsory quarantine & Yes & Yes & Yes \\
\hline State-organized quarantine & No & Partly* & Yes \\
\hline Closure of borders & Yes & Yes & Yes \\
\hline Closure of schools & Yes & Yes & Yes \\
\hline
\end{tabular}

* For defined groups

Source: authors

\section{THE TIMING OF PUBLIC POLICY RESPONSES}

Our data show differences in the timing of the core anti-pandemic measures along three time axes, country by country. The Czech data (Table 2) indicate that the (almost full) set of critical measures was adopted, but with some delay after the detection of the first COVID-19 case.

The Russian data (Table 2) document a relatively early response to the first wave of COVID-19 from China, but a significant delay of the comprehensive reaction to the import of COVID-19 from Europe. Real critical federal and Moscow measures did not start until up to one month after the detection of the first COVID-19 case in Moscow, which was imported from Italy.

The Slovak case (Table 4) documents the comprehensive and early reaction of the "leaving" government, followed by some additional specific measures introduced by the new Matovic government, particularly the compulsory state-organized quarantine. Some critical measures started even before the detection of the first COVID-19 case, the rest just few days afterwards. After the level of infection increased, more measures were introduced.

\section{PUBLIC POLICY MEASURES SUPPORTING COMPLIANCE WITH ANTI-PANDEMIC MEASURES}

This part is again based mainly on expert opinions. According to these experts, the most important "compliance" measure was publicly informing citizens about the pandemic and all its aspects (nine votes). However, several experts criticized governments and media for creating COVID-19 hysteria. In Slovakia, all the experts mentioned the specific role of publishing official Slovak prognoses 
Tab. 2: Timing of public policy responses: Czechia

\begin{tabular}{|c|c|c|}
\hline Measure & Date & Remark \\
\hline Direct flights between China and Czechia suspended & February 9 & Indefinitely \\
\hline National Security Council (BRS) met & February 25 & No restrictive measures adopted at that time. \\
\hline \multicolumn{3}{|l|}{ March 1, 2020: first 3 COVID-19 cases reported in Czechia } \\
\hline Biathlon World Cup in Nové Město held without audience & March 2 & \\
\hline Flight connections with South Korea, Northern Italy suspended & March 5 & \\
\hline Ban on all mass activities with more than 100 persons & March 10 & Limit later reduced to 30 persons \\
\hline School closures & March 11 & Except kindergartens \\
\hline State of emergency declared & March 12 & Prolonged several times, lasted until May 17 \\
\hline Mandatory home quarantine for returnees from abroad & March 12 & \\
\hline Restaurant closures & March 13 & \\
\hline Sport and similar facilities closed & March 13 & \\
\hline Shop closures & March 14 & With exceptions (food, groceries...) \\
\hline Central Emergency Board activated & March 15 & $\begin{array}{l}\text { As a working committee of the National } \\
\text { Security Council }\end{array}$ \\
\hline Border closures & March 16 & \\
\hline Restrictions on free movement & March 16 & $\begin{array}{l}\text { Work, shopping, nature outings and similar } \\
\text { allowed }\end{array}$ \\
\hline Regional quarantine & March 16 & Litovel, Uničov, Červenka (14 days) \\
\hline Compulsory use of protective masks everywhere & March 19 & \\
\hline Relaxation of measures started & Late April & According to pre-announced schedule \\
\hline Re-emergence of COVID-19 & Late June & $\begin{array}{l}\text { Significant (June } 27-29 \text { ) daily increase of more } \\
\text { than } 200 \text { cases. Local centers (Karviná) }\end{array}$ \\
\hline
\end{tabular}

Source: authors

predicting COVID-19 spread (the numbers were highly overestimated) with two scenarios (with and without protective measures). Two of them emphasized this factor specifically:

"Information about the situation abroad and our published prognoses created fear and motivated compliance."

"At the beginning, the important factor was fear, caused by international developments and preliminary prognoses published by the Ministry of Health. The government communication in media and by official pages 'promoted such fear'."

According to experts, the second most important "compliance" factor was the fact that the Prime Minister and all other government officials used protective masks when staying in public spaces, thereby motivating compliance (eight votes). It is a bit surprising that these experts did not have a common opinion on the use of such masks by politicians and top bureaucrats when delivering speeches in the media (five yes, five no). One Russian expert even stated:

"This did not work for citizens with a low level of trust; such speeches may have had the opposite effect-this type of citizen started to believe that this was done with the aim of further escalating the situation in the interests of the authorities."

The third ranked measure is the establishment of special COVID-19 telephone numbers for first contact. The Czech and Slovak experts did not like the fact that the Prime Minister appeared in the media too frequently_ "too much is not effective" or "their information was frequently chaotic" and also did not propose using penalty code sanctions to punish non-compliance (all the Russian experts did). A certain argument was added by experts from all three countries: the need for active co-operation with NGOs, civil society, and self-governments in explaining measures, uniting society, and encouraging compliance with the requirements.

Table 5 indicates that all three countries tried to promote compliance with anti-pandemic measures in a relatively comprehensive way. However, it also shows some differences, such as the Slovak prognoses and slightly less effort on the Russian side. 
Tab. 3: Timing of public policy responses: Russia

\begin{tabular}{|c|c|c|c|}
\hline Level & Measure & Date & Remark \\
\hline Federal & $\begin{array}{l}\text { Operational headquarters established to combat } \\
\text { COVID-19 }\end{array}$ & January 27 & $\begin{array}{l}\text { Under the leadership of Deputy } \\
\text { Prime Minister }\end{array}$ \\
\hline Federal & $\begin{array}{l}\text { National Plan for the Prevention of Import and } \\
\text { Spread of COVID-19 }\end{array}$ & January 31 & \\
\hline \multicolumn{4}{|c|}{$\begin{array}{l}\text { January 31, 2020: first COVID-19 cases reported in Russia-two people from China (in the cities of Tyumen and Chita, both in } \\
\text { Siberia, recovered) }\end{array}$} \\
\hline Federal & First border control measures & January 28 & $\begin{array}{l}\text { Emergency regime in two regions on } \\
\text { Chinese border }\end{array}$ \\
\hline Federal & Closure of borders with China & February 20 & \\
\hline \multicolumn{4}{|c|}{ March 1: the first case in Moscow-a Russian returning from Italy } \\
\hline Federal & Border control with other countries & Early March & Restriction of air traffic with the EU \\
\hline Federal & $\begin{array}{l}\text { Closure of schools and universities, restrictions } \\
\text { on cultural and sports activities }\end{array}$ & March 16-18 & Voluntary action in some regions \\
\hline Federal & $\begin{array}{l}\text { Closure of borders to foreigners and cancellation } \\
\text { of flights from many high-risk countries }\end{array}$ & March 16-17 & $\begin{array}{l}\text { Mandatory 14-day quarantine for } \\
\text { people arriving in Russia }\end{array}$ \\
\hline Moscow & $\begin{array}{l}\text { Self-isolation (home quarantine) for people aged } \\
\text { over } 65 \text { years and those with chronic illness }\end{array}$ & $\begin{array}{l}\text { End of March } \\
(23 \mathrm{rd})\end{array}$ & Paid sick leave for those employed \\
\hline Federal & Lockdown during Easter holidays & $\begin{array}{l}\text { March 30-April 3, } \\
\text { extended until end } \\
\text { of April }\end{array}$ & $\begin{array}{l}\text { Wages paid, some stores or similar } \\
\text { open }\end{array}$ \\
\hline Federal & $\begin{array}{l}\text { Full closure of borders for both Russians and } \\
\text { others }\end{array}$ & March 30 & \\
\hline Federal/Moscow & $\begin{array}{l}\text { Introduction of self-isolation (home-quarantine), } \\
\text { except for defined reasons }\end{array}$ & March 30 & $\begin{array}{l}\text { Moscow defined following reasons to } \\
\text { leave the house: } \\
\text { emergency medical care; work, } \\
\text { nearest store, walking pets, taking } \\
\text { out the trash }\end{array}$ \\
\hline Moscow & Closure of non-food shops and services & March 30 & \\
\hline Moscow & $\begin{array}{l}\text { Obligatory wearing of masks and gloves in public } \\
\text { areas }\end{array}$ & April 12 & \\
\hline Moscow & $\begin{array}{l}\text { Electronic passes introduced to move around the } \\
\text { city }\end{array}$ & April 15 & $\begin{array}{l}\text { Two per week with certain } \\
\text { exemptions }\end{array}$ \\
\hline Federal & Recommendations to ease measures issued & May 9 & $\begin{array}{l}\text { Framework plan, specific criteria, } \\
\text { implementation by regions }\end{array}$ \\
\hline Moscow & Easing of measures started & June 6 & Phased measures \\
\hline
\end{tabular}

Source: authors

\section{DISCUSSION AND CONCLUSIONS}

Our study compared the three selected countries that have similar historical path-dependency situations but rather different COVID-19 pandemic mortality and morbidity results. To estimate the links between the "quality" of public policy responses to COVID-19 and its health impacts (with a focus on morbidity) we decided, based on the literature review, to analyze three dimensions- the scopel scale of public policy anti-pandemic responses, the timing of these responses and the level of success in creating a "compliance atmosphere" in society. 
Tab. 4: Timing of public policy responses: Slovakia

\begin{tabular}{|c|c|c|}
\hline Measure & Date & Remark \\
\hline Activation of crisis management structures & February 27 & Crisis Crew activated. First meeting on March 6. \\
\hline First border control measures & February 14 & $\begin{array}{l}\text { Temperature measuring at border crossings, information } \\
\text { campaign }\end{array}$ \\
\hline $\begin{array}{l}\text { Closure of schools-voluntary action in some regions } \\
\text { plus universities }\end{array}$ & March 4 & \\
\hline \multicolumn{3}{|l|}{ March 6, 2020: first COVID-19 case reported in Slovakia } \\
\hline Ban on all mass activities & March 9 & \\
\hline Emergency situation announced & March 11 & Lasted for go days \\
\hline Full closure of schools ordered & March 12 & \\
\hline Closure of borders & March 12 & \\
\hline Compulsory quarantine & March 12 & \\
\hline Sport and similar facilities closed & March 13 & \\
\hline Most shops and services closed & March 16 & $\begin{array}{l}\text { Food, groceries and selective urgent services kept in } \\
\text { operation }\end{array}$ \\
\hline Compulsory use of protective masks everywhere & March 25 & \\
\hline $\begin{array}{l}\text { State-organized quarantine for all arriving to the } \\
\text { country }\end{array}$ & April 6 & \\
\hline Lockdown & April 8-13 & Temporary lockdown during Easter holidays \\
\hline Regional lockdown & April & $\begin{array}{l}\text { Seven Roma settlements quarantined for two weeks and one } \\
\text { for almost four weeks }\end{array}$ \\
\hline Relaxing of measures starts & Late April & According to pre-announced schedule \\
\hline Re-emergence of COVID-19 & July & Not critical yet, primarily imported cases \\
\hline
\end{tabular}

Source: authors

Tab. 5: Compliance supporting measures

\begin{tabular}{llll}
\hline & Czechia & Russia & Slovakia \\
\hline Regular supply of public information about pandemic & Yes & Yes & Yes \\
\hline Own pandemic spread prognoses & Yes & Yes & Yes* \\
\hline $\begin{array}{l}\text { Use of protective masks by top politicians and bureaucrats in public } \\
\text { spaces }\end{array}$ & Yes & Partly & Yes \\
\hline Special COVID-19 telephone lines & Yes & Yes & Yes \\
\hline Involving NGOs and civil society & Partly & Partly & Partly \\
\hline
\end{tabular}

*Unrealistic, excessively negative prognosis

Source: authors

Our results are quite interesting. The countries do not differ greatly in terms of the scope and scale of responses-the only fact to mention in this connection is that Slovakia carried out the most comprehensive system of quarantine measures. The expert opinions suggest that there is a certain "minimum list" of effective anti-pandemic measures to be implemented by national governments to limit the spread of COVID-19.

Our findings also suggest that (except for the scope and scale of responses), the timing of public policy responses may be a critical factor. The fact that the sample countries differ on this point (Russia significantly) may be a possible explanatory factor for the different results. Slovakia, with the best "pandemic figures" started with its first critical reactions even before the first COVID-19 
case was registered in the country, and it implemented core measures soon after "day zero". Czechia, with the second best "pandemic figures" reacted with some minor delay; Russia was rather late.

In all three countries, governments tried to create an atmosphere supporting compliance with anti-pandemic measures, but in slightly different ways and also with varying levels of success. It is not possible to state exactly, but our experts suggest that the overpessimistic prognoses of the Slovak government managed (intentionally or unintentionally) to create a real fear of COVID-19 in the society — and as a result, a high level of compliance with most measures was achieved. In Czechia, the level of compliance was also high; neither the media nor the experts reported any critical problem related to this. The level of compliance in Russia was a little bit more problematic; for example, some people did not follow the rule to use protective masks. Our data did not prove for sure that different levels of compliance are the result of the "quality" of public policy responses to COVID-19. However, our analysis suggests that some correlation exists.

What failed to work in all three countries was the idea of voluntary compliance with home quarantine. Even in Slovakia (the most disciplined country) the number of cases of people not following this rule was high (and not only among less-educated residents). In the first phase, COVID-19 was imported by tourists returning from ski resorts in Italy and Austria (including medical doctors, who returned to work immediately after coming back from holidays - and infected their patients). The government first reacted with state-organized quarantine, and when the problem returned in July, by passing the law on monitoring the mobile phones of all the people arriving from "risky" countries.

Our results suggest that timing and promoting compliance may be factors explaining the success or failure of anti-pandemic reactions of national governments. However, we are also aware of the limitations of this study. One of them is the large size of Russia, which did not allow us to cover the country as a uniform subject—but it seems that this did not influence our findings significantly. As already indicated, country size should not impact relative mortality and morbidity indicators much. Moreover, Moscow is a very large megapolis (many other similarly large cities did not suffer much from the pandemic_-for example, Hong Kong, with an even greater population density).

Another limitation is the nature of the method used, and this cannot be avoided. Qualitative comparative policy analysis defines a combination of conditions (independent variables) that eventually produce a phenomenon - the outcome (dependent variable) to be explained. Our findings suggest that the timing of public policy responses and the success in creating a "compliance atmosphere" may be critical factors in success or failure in fighting the COVID-19 pandemic, but we cannot confirm this. To obtain more sophisticated results, interdisciplinary research would be necessary. Despite this, the value of this study is that it provides important information for future comparative research.

The final core limitation is the phasing problem. Czechia and Slovakia had almost eliminated the spread of COVID-19 in May 2020; in mid-July, Russia remained in a phase of a relatively high rate of new infections. However, in June/July 2020, Czechiaespecially, but to a lesser extent also Slovakia—faced the "return" of COVID-19. In July, Czechia had more than 100 new cases daily and the total number of actively infected is similar to the first peak. However, such a development just confirms our findings about the importance of compliance and early reaction (missing for this may be "second" COVID-19 phase in Czechia).

\section{ACKNOWLEDGEMENT}

Preparation of this paper received support from a project of the Czech Science Foundation (GA19-06020S).

\section{REFERENCES}

Amat, F., Arenas, A., Falco-Gimeno, A. and Munoz, J., 2020, Pandemics meet democracy: Experimental evidence from the COVID-19 crisis in Spain. Available at https://osf.io/preprints/socarxiv/dkusw/, (accessed 26 June 2020).

Ang, Y.Y., 2020, When COVID-19 Meets Centralized, Personalized Power. Nature Human Behavior, 4, pp. 445-447. doi: 10.1038/s41562-020-0872-3
Bouckaert, G., Galli, D., Kuhlmann, S., Reiter, R. and Van Hecke, S., 2020, European Coronationalism? A Hot Spot Governing a Pandemic Crisis. Public Administration Review. First published: 22 May 2020, available at https://onlinelibrary.wiley.com/doi/abs/10.1111/puar.13242, (accessed 27 June 2020). doi:10.1111/puar.13242 
Bozorgmehr, K., Saint, V., Kaasch, A., Stuckler, D. and Kentikelenis, A., 2020, COVID and the convergence of three crises in Europe. Lancet Public Health, 5(5), pp. 247-248, doi: 10.1016/S2468-2667(20)30078-5

Cascella, M., Rajnik, M., Cuomo, A., Dulebohn, S.C. and Di Napoli, R., 2020, Features, Evaluation and Treatment Coronavirus (COVID-19), available at https://www.ncbi.nlm.nih.gov/books/NBK554776, (accessed 27 June 2020).

Djalante, R., Lassa, J., Setiamarga, D., Sudjatma, A., Indrawan, M., Haryanto, B., Mahfud, Ch., Sinapoy. M.S., Djalante, S., Rafliana, I., Gunawan, L.A., Surtiari, G.A.K., and Warsilah, H., 2020, Review and analysis of current responses to COVID-19 in Indonesia: Period of January to March 2020. Progress in Disaster Science, 6 (2020), doi:10.1016/j. pdisas.2020.100091

Hale, T., Webster, S., Petherick, A., Phillips, T. and Kira, B., 2020, Oxford COVID-19 Government Response Tracker. Oxford: Blavatnik School of Government.

Huang, I.Y.F., 2020, Fighting Against COVID -19 through Government Initiatives and Collaborative Governance: Taiwan Experience. Public Administration Review. First published 22 May 2020, available at https:// onlinelibrary.wiley.com/doi/full/10.1111/puar.13239?af=R, (accessed 30 June 2020,doi:10.1111/puar.13239).

Hudson, J. and Kuhner, S., 2017, Qualitative comparative analysis and applied public policy analysis: New applications of innovative methods. Policy and Society, 32(4), pp. 279-287, doi: 1016/j.polsoc.2013.10.001

Christensen, T. and Lægreid, P. (2020), "Balancing governance capacity and legitimacy - how the Norwegian government handled the COVID -19 crisis as a high performer." Public Administration Review, First published: 22 May 2020, available at https://onlinelibrary.wiley.com/doi/ abs/10.1111/puar.13241, ( accessed 27 June 2020).

McKibbin, W. and Roshen, F., 2020, The Global Macroeconomic Impacts of COVID-19: Seven Scenarios. CAMA Working Paper 19/2020. Doi:10.2139/ ssrn. 3547729

Moloney, K. and Moloney, S., 2020, Australian Quarantine Policy: From Centralization to Coordination with mid-Pandemic COVID-19 Shifts. Public Administration Review, first published 19 May 2020, available at https://onlinelibrary.wiley.com/doi/full/10.1111/puar.13224?af=R, (accessed on 29 June 2020), doi:10.1111/puar.13224

Peixoto, V. R., Vieira, A., Aguiar, P., Sousa, P. and Abrantes, A. V., 2020, Timing", adesão e impacto das medidas de contenção da COVID-19 em Portugal. Lisboa: Escola Nacional de Saúde Pública.

Rihoux, B., Rezsohazy, I. and Bol, D., 2011, Qualitative Comparative Analysis (OCA) in Public Policy Analysis: An Extensive Review. German Policy Studies, 7(3), pp. 52-58.
Yu, L. and Saltman, R.B. 2020 Policy Lessons from Early Reactions to the COVID-19 Virus in China. American Journal of Public Health, published Online: July 08, 2020, available at https://ajph.aphapublications.org/doi/ full/10.2105/AJPH.2020.305732, (accessed 30 June 2020).

Shawa, R., Yong-kyun, K. and Hua, J., 2020, Governance, technology and citizen behavior in pandemic: Lessons from COVID-19 in East Asia. Progress in Disaster Science 6 (2020), doi:10.1016/j.pdisas.2020.100090 WHO, 2020, Responding to community spread of COVID-19. Interim guidance. New York: WHO 